\title{
MULTIPLEX PCR METHOD FOR DETECTION OF VARIABILITY IN GENES ENCODING THE ALPHA PROTEINS OF Streptococcus agalactiae
}

\author{
BARBORA VIDOVÁ ${ }^{1,2}$, MICHAL CHOTÁR ${ }^{2}$, JOZEF TIMKO $^{2}$ \\ ANDREJ GODÁNY ${ }^{2,3}$ \\ ${ }^{1}$ Institute of Biochemistry, Nutrition and Health, Slovak University of Technology, \\ SK-812 37 Bratislava, Slovak Republic (barbora.vidova@savba.sk) \\ ${ }^{2}$ Institute of Molecular Biology, Slovak Academy of Sciences \\ SK-845 51, Bratislava, Slovak Republic \\ ${ }^{3}$ Department of Biotechnology, University of SS. Cyril and Methodius, \\ SK-917 01 Trnava, Slovak Republic
}

\begin{abstract}
The majority of Streptococcus agalactiae strains express one or more surface-anchored proteins that vary by strain. These proteins, which are characteristic for S. agalactiae, and are able to induce protective antibodies, include the alpha $\mathrm{C}$, Rib proteins, alpha-like protein 2 , and alpha-like protein 3 . In this study was developed multiplex PCR method for detection of genes encoding these proteins, and its occurrence within a various S. agalactiae isolates of bovine origin. Also are reported two new genes from bovine isolates of $S$. agalactiae amplified by PCR, encoding other putative members of the family, alphalike protein 6 , and alpha-like protein 7 . They contain an overall genetic organization highly similar to that of the alpha $\mathrm{C}$ and Rib proteins.
\end{abstract}

Key words: Streptococcus agalactiae, alpha-like family, variability, multiplex PCR

\section{Introduction}

The importance of Streptococcus agalactiae as a major perinatal pathogen for invasive disease has been well documented (BAKER and EDWARDS, 2000; ZALEZNIK et al., 2000; FERRIERI, 1997). The S. agalactiae first received attention as a cause of bovine mastitis, a disease defined as 'inflammation of the mammary gland', that cause the losses in a diary industry associated with clinical and subclinical mastitis, which arise from the costs of treatment, culling, death and decreased milk production (BRADLEY, 2002). Epidemiological studies of S. agalactiae infections are mainly based on capsule serotyping. The capsule is an antigenic determinant and a major virulence factor as it interferes with complement mediated killing (EDWARDS et al., 1982). The S. agalactiae strains are classified into nine different serotypes based on differences in the capsular polysaccharide antigens Ia, Ib, and II through VIII (PAOLETTI et al., 2000). Serotype distribution varies with geographical region and ethnic origin, and the virulence of clinical isolates with similar capsular composition can also vary widely, suggesting that other bacterial virulence factors, except a capsule, are involved in the pathogenesis of S. agalactiae (SPELLEBERG, 2000). In addition, several surface-anchored proteins that vary by strain have been described for S. agalactiae (MOYO et al., 2002; KVAM et al., 1995). 
The proteins include the immunoglobulin A-binding beta $\mathrm{C}$ protein $(\mathrm{C} \beta)$ encoded by bac, the alpha $\mathrm{C}$ protein $(\mathrm{C} \alpha)$ (BEVANGER and MAELAND, 1979) encoded by bca (MICHEL et al., 1992), and the proteins R1, R3, and R4 (FLORES and FERRIERI, 1996, 1989; LANCEFIELD and PERLMANN, 1952). The $\mathrm{C} \alpha$ and the R proteins belong to a family of so-called "ladder-forming" proteins, a designation based on the banding patterns generated on Western blotting (WÄSTFELT et al., 1996). Some of the best characterized protein antigens used as candidate vaccines belong to the Alpha protein family, reviewed by LINDAHL et al. (2005). These major antigens are encoded by allelic genes. Five different alleles, named Alp2, Alp3, Rib, R28 and Epsilon (alpha-like proteins) have been described (LACHENAUER et al., 2000; LACHENAUER and MADOFF, 1996; WÄSTFELT et al., 1996; STÅLHAMMARCARLEMALM et al., 1993). All these proteins are encoded by stable mosaic genes, generated by a recombination of modules at the same chromosomal locus (LACHENAUER et al., 2000). The proteins exhibit size variation between strains depending on the number of repeats in the corresponding gene. Moreover, it has been demonstrated that, in the course of infection, the number of repeats inside the alpha $\mathrm{C}$ proteins can undergo internal deletions as a means for evading the host immune response (MADOFF et al., 1996). Diversity of S. agalactiae strains has been analyzed using a broad range of methods. Aside from serotyping and multilocus enzyme electrophoresis (MLEE) (MUSSER et al., 1989), a method based on primary structures of proteins, other typing methods used are DNA based. These include ribotyping (BLUMBERG et al., 1992), random amplified polymorphism (LIMANSKY et al., 1998), pulsed field gel electrophoresis (ROLLAND et al., 1999; GORDILLO et al., 1993) and more recently, multilocus sequence typing (MLST) (JONES et al., 2003).

The study of surface proteins and their genes encoding sequences is important from the aspect of epidemiological analysis of the infections caused by Streptococcus agalactiae, and simultaneously, surface proteins hold capability to be used in vaccines against this pathogen (MAIONE et al., 2005; LARSSON et al., 2004; PAOLETTI and MADOFF, 2002; BRODEUR et al., 2000). The aim of the present study was to analyse the gene content, which could indicate distribution of surface proteins, in the set of bovine $S$. agalactiae isolates. This was performed by multiplex PCR method for detection of genes $b c a$, rib, alp2/3, alp4, and alp5 directly according the PCR products sizes.

\section{Materials and methods}

\subsection{Bacterial strains and media}

The streptococcal isolates were obtained from different farms in Slovakia (147 strains) and from Czech republic (5 strains), and could be identified as Streptococcus agalactiae belonging to Lancefield's serological group B. The identification was performed by PCR identification (CHOTÁR et al., 2006). S. agalactiae cultures were grown overnight on Todd-Hewitt (Biomark) broth at $37^{\circ} \mathrm{C}$ on rotary shaker. 


\subsection{Preparation of bacterial cell suspension for PCR}

One milliliter of overnight culture was transferred in sterile tube and centrifuged at 10.000 RPM for $3 \mathrm{~min}$, pellet was washed twice with sterile distilled water, once with 0.1 M Phosphate Buffered Saline, pH 7.2 (PBS), and then resuspended in $1 \mathrm{~mL}$ of deionized sterile water to allow the burst of bacterial cells. Samples of $2 \mu \mathrm{L}$ of these preparations were used directly for PCR.

\subsection{PCR conditions}

Reactions were carried out in final volume of $20 \mu \mathrm{L}$. The reaction mixture contained $0.5 \mathrm{U}$ DyNAzyme ${ }^{\mathrm{TM}}$ DNA polymerase (Finnzymes), $0.4 \mu \mathrm{L} 10 \mathrm{mM}$ dNTP Mix (Finnzymes), $4 \mu \mathrm{L}$ Optimized DyNAzyme ${ }^{\mathrm{TM}}$ 10x reaction buffer (Finnzymes). Primers listed in Table 1 were used in concentrations: $0.5 \mu \mathrm{M}$ of universal forward primer SAGANf, and reverse primers were added as follows $0.16 \mu \mathrm{M}$ of SAGA4, 0.4 $\mu \mathrm{M}$ of SAGArib, $0.7 \mu \mathrm{M}$ of SAGAalpC, $0.9 \mu \mathrm{M}$ of SAGA2/3, and $1.3 \mu \mathrm{M}$ of SAGANr. All DNA oligonucleotides were synthesized by Sigma.

Table 1. Oligonucleotide primers used in this study.

\begin{tabular}{cclc}
\hline \multicolumn{2}{c}{ Primers } & \multicolumn{1}{c}{ Sequences 5'-> 3' } & $\begin{array}{c}\text { Size } \\
\text { (bp) }\end{array}$ \\
\hline Reverse: & SAGAalpC & TAT ATG TGG TAG TCG ATC TTC ACC & 428 \\
& SAGArib & CAC ACT GAA CTT TTA AAC CAA GTG A & 325 \\
& SAGA2/3 & CAT TCA GAT TAT TAT AAT ATA TAG CAC & 630 \\
& SAGA4 & TTA ATAT GCA CTG GAT TAA CTC CAC & 140 \\
& SAGANr & CGC GGA TCC ATC CTC TTT TTT CTT AGA AAC & 852 \\
Forward: & SAGANf & GGA ATT CCA TAA TGT TTA GAA GGT CTA AAA A & \\
\hline
\end{tabular}

Two microliters of bacterial suspension was used as a template. The amplification program consisted of denaturation at $96^{\circ} \mathrm{C}$ for $5 \mathrm{~min}, 30$ cycles of denaturation at $96^{\circ} \mathrm{C}$ for one minute, annealing at $55^{\circ} \mathrm{C}$ for one minute and extension at $72^{\circ} \mathrm{C}$ for two minutes, followed by a final extension at $72^{\circ} \mathrm{C}$ for 8 minutes. Ten microliters of PCRamplified product was analyzed by electrophoresis in $0.9 \%$ agarose gel stained with ethidium bromide. This was carried out in 1x BBE ( $0.65 \mathrm{M}$ boric acid, $29 \mathrm{mM}$ sodium tetra borate, $250 \mathrm{mM}$ EDTA, $\mathrm{pH}$ 7.8). PCR amplicons were analyzed by UV transluminization.

\subsection{DNA sequence analysis}

PCR products were sequenced and compared with GeneBank sequences using BLAST (Basic Local Alignment Search Tool) (Altschul et al., 1990). The new sequences generated during this study have appeared in GeneBank with the following accession numbers: DQ629924 (alp6) and DQ629925 (alp7). Previously published gene sequences used in this study and their GeneBank accession numbers are as follows: M97256 (bca), U58333 (rib), AY345596 (alp1), AJ488912 (alp4) and AY461799 (alp5). 


\section{Results and discussion}

Alpha proteins of Streptococcus agalactiae have typical repetition region consisted of about 80 amino acids, which are highly homologous (LINDHAL et al., 2005). While these repeats present extensive homology between alpha-protein-like proteins, the N-terminal portion is distinctive. The analysis of a ClustalW amino acid multisequence alignment of the N-terminal portions of the AlpC, Rib, Alp2, Alp3, Alp4 and Alp5 identified distinctive strings for each protein, except for the Alp2 and Alp3 proteins, which are identical over the first half of their length. Primer nucleotide sequences corresponding to the distinctive strings were used in a multiplex assay as the reverse primers, while a nucleotide string, common to all the surface protein genes, was used as the forward primer (Table 1). These primers allowed detection of nucleotide sequences specific for single Alp proteins, discriminated according to the size of PCR product, which directly indicated the presence of gene encoding specific Alp protein. These primers were used to screen 152 isolates S. agalactiae of bovine origine by multiplex PCR. Representative results are shown on Fig. 1. Results derived from the direct analysis of amplicon size were correlated with the gene sequence of the corresponding amplified product for each individual strain. By this multiplex analysis in set of bovine isolates were identified 31 isolates with gene encoding AlpC protein, 50 isolates with sequence for gene encoding Rib, 39 isolates with Alp $2 / 3$ coding sequence, 10 isolates with gene alp4, and 6 isolates with gene alp5. Also two another amplicons with significantly longer lengths $1.095 \mathrm{bp}$ and $1.347 \mathrm{bp}$ were found. The amplicon with 1.095 bp length was found in case of 9 strains, namely 245, 251, 252, $256,257,259,264,347$ and 348 , the amplicon with 1.347 bp length was detected in 2 strains, $1925 / 3$ and $2285 / 1$ (Fig. 1.). All these amplicons were sequenced and compared by BLAST. PCR with DNA S. agalactiae from the strain 341 resulted an amplicon with length $852 \mathrm{bp}$, that was $99.5 \%$ identical to original alp5 from strain 27 . Comparison showed the differences in nucleotide sequence observed on 23rd, 25th, 29th and 81st nucleotide downstream, that resulted in change of 3 amino acids at Nterminal coding region of translated protein. The amplicon sequence of alp6 showed considerable homology with alp4, bca, rib and other members of the surface protein gene family defined by bca-rib. The homologous regions were located at the 5 ends of the genes (for bca, the positions are in region between nucleotides 251 and 559, and for the corresponding amino acid sequence, they are between positions 58 and 160). The ratios of similarity to DNA sequences of alp4, bca, rib, alp2 and alp3 are $89 \%, 73$ $\%, 66.9 \%, 62.4 \%$ and $62.3 \%$, respectively.

The proteins belonging to the alpha-like protein family are of interest as models for other repetitive proteins, which are common in gram-positive bacteria (KONG et al., 2002; LACHENAUER et al., 2000). This typical feature was not recognized in alp6, but its sequence is the most similar to that of bca, which encodes $\mathrm{C}$ alpha, the prototype of the surface protein family, here it is proposed, that the gene could be considered as putative alpha-like protein. In the case of two isolates, 1925/3 and 2285/1, was observed the PCR product with 1.347 bp length, and was named alp7. Sequencing of this amplicon and its comparison by BLAST showed similarity to the members of alpha-like family; in particular alp1, alp5 and bca, the ratios of similarity 
were $82.8 \%, 88.2 \%$ and $77 \%$, respectively. The homologous regions were located at the $5^{\prime}$ ends of the genes, whereas for alp1 and alp5 the positions are in the region between nucleotides 297 to 710 . The nucleotide sequence organization in alpha-like family proteins is similar to that in many surface proteins of gram positive bacteria. An $\mathrm{N}$-terminal signal sequence is followed by a nonrepeated $\mathrm{N}$-terminal region, a repeated region, a wall anchoring region by which the protein is anchored to the cell wall via a structure close to the C-terminus consisting of an LPXTG sequence motif followed by a membrane-spanning hydrophobic region and a charged sequence (DESWAUX et al., 2006; WÄSTFELT et al., 1996; MICHEL et al., 1992).

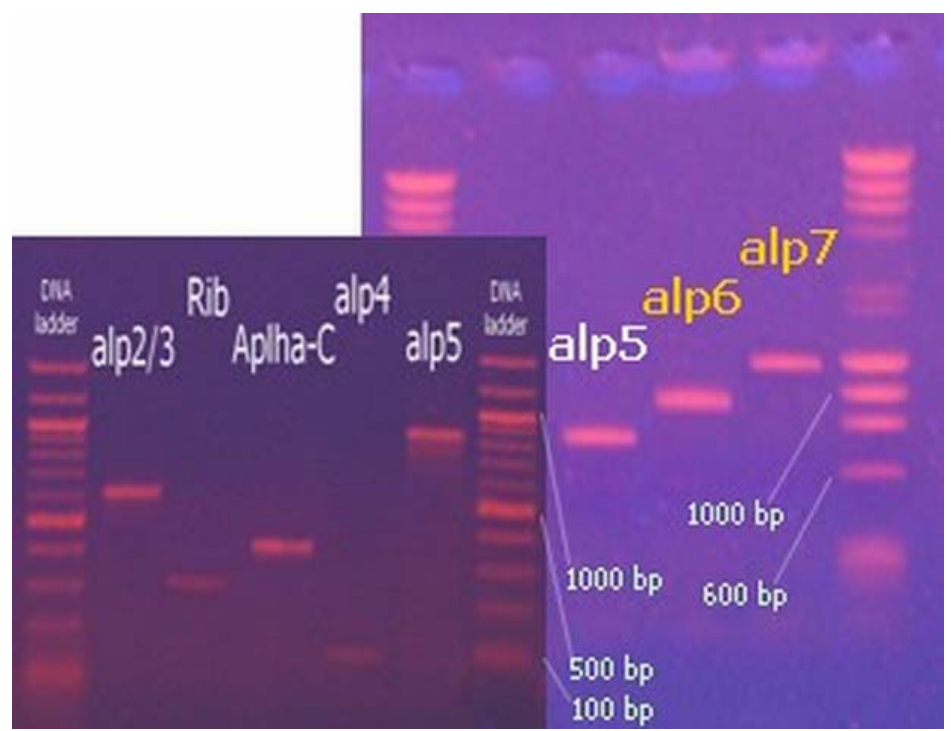

Fig. 1. Elecrophoresis of multiplex PCR for detection of presence the genes encoding Alp proteins, alp2/3, Rib, AlphaC, alp4, and alp5, discriminable by PCR product size on $0.9 \%$ agarose gel. Other two new genes were also detected in the set of S. agalactiae bovine isolates, alp6 and alp7. DNA ladder represents molecular size marker (Finnzymes).

A repetitive structure in amino acid sequence is conserved and was remarked also in nucleotide sequence of alp7, where differ in the last one base pair, which had no impact to the amino acid sequence. This tandem repeat consists of 82 amino acid residues, whereas one consists of 246 base pairs repetition. The alp7 tandem repeat motif is similar to that of alp1, alp4, bca and rib, with the ratios of similarity $93.9 \%$, $91.7 \%, 91.6 \%$ and $44 \%$, respectively (Fig. 2.).

It has been supposed, that the repeat region may act as a rod needed for exposure of the unique ligand-binding region (LUO et al., 2000; HAMBURGER et al., 1999). The LPXTG motif was found in both, alp6 and alp7, amino acid sequences, whereas in for this part of sequence in alp7 was observed similarity related to immunoglobulin A1 protease. Because domains with the Ig-like fold are often implicated in molecular recognition it could has such function (CALLEBAUT et al., 2000). Like many other surface proteins of gram-positive bacteria, alpha-like protein family members, also 
with recently here reported, lack cysteine residues. The importance of alpha-like surface proteins consists in the facts, that these proteins play a role as serotype markers, may be important in the pathogenesis of $S$. agalactiae disease, and may be considered vaccine candidates (MAELAND et al., 2004). They play an important role as serotype markers, because were noted relationships between serotypes and surface protein genes occurrence (KONG et al., 2002), eg. protein AlpC is commonly expressed with serotype Ib or II, protein Rib with serotype III, and Alp3 protein with serotype V (PERSSON et al., 2008). S. agalactiae strains are typical in high variability on the gene level, and genes under high selection pressure could undergo to various mutations.

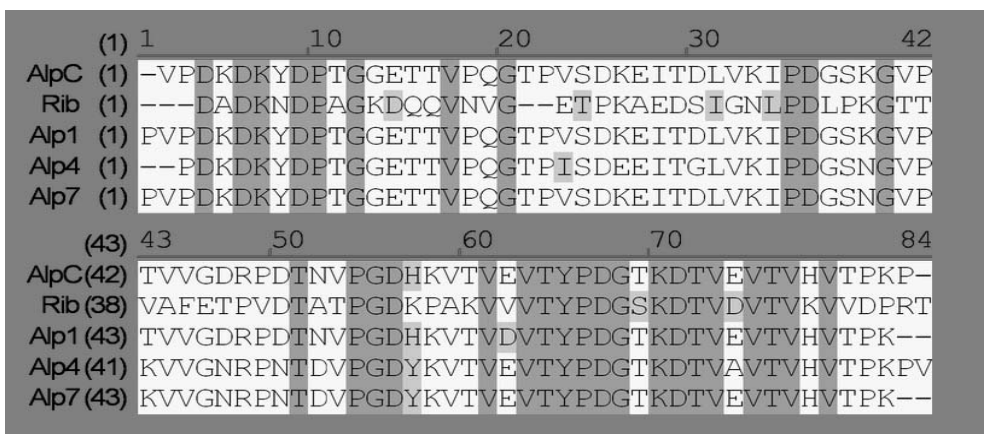

Fig. 2. Multiple sequence alignments of the deduced amino acid sequences of the repeat regions of the selected alpha-like proteins. Alignments of the repeat regions illustrated conserved motifs near the beginnings and the ends of the repeats. Black boxes indicate identity and gray boxes indicate similarity. AlpC, alpha C protein repeat element, Rib, repeat element from protein Rib, Alp1, alpha-like repeat element from Alp1, Alp4, alpha-like repeat element from Alp4, and Alp7, alpha-like repeat element from Alp7.

The results of this study indicate that the genes encoding surface proteins were found to constitute a heterogeneous group, with no particular gene dominating. The genes studied here were found in all of the bovine isolates. In the set of bovine isolates was the most common gene encoding protein Rib (34\%). The overall distribution of these genes was similar to that reported previously (ZENG et al., 2006; KONG et al., 2002; LACHENAUER et al., 2000). In this study are also reported two new putative members of this family. Like the alpha $\mathrm{C}$ and Rib protein genes, these genes each contain conserved $\mathrm{N}$ - and $\mathrm{C}$-terminal encoding regions, and a tandem repeat region was recognized in amino acid sequence of alp7. It has been previously reported, that with a few exceptions, $S$. agalactiae strains of a given polysaccharide serotype contain the same alpha-like protein, disregarding tandem repeat number (LACHENAUER et al., 2000, 1999). This concordance may reflect clonal linkages within a species that is naturally incompetent and consistent with several studies showing a predominance of individual clones among S. agalactiae isolates (BLUMBERG et al., 1996). Alternatively, it is conceivable that there is a functional linkage between the alpha-like proteins and polysaccharide serotype that would require this specificity. Because of a relatively low occurrence of the alp6 and alp7 within the set of bovine isolates and dependence of their presence on a geographical locality, these genes of the alpha-like 
protein family could not be designated for the detection of $S$. agalactiae, but they could be proof of the biological variability within this protein family. Furthermore, characterisation of variability in expression of surface proteins is very important with the perspective of surface proteins application in vaccine development. In this context, it is extremely important to have a rapid and reliable molecular test, as here reported multiplex PCR method, capable of determining S. agalactiae surface protein genes by direct evaluation of amplicon size, which would permit extensive epidemiological studies on the profiles of protein subtypes of circulating $S$. agalactiae strains without consuming additional resources.

Acknowledgements: The work was supported by projects of the Ministry of Agriculture of Slovak Republic (2003 SP 27/028, OE 02/028, OE 02-01-03).

\section{References}

ALTSCHUL, S.F., GISH, W., MILLER, W., MYERS, E.W., LIPMAN, D.J.: Basic local alignment search tool. J. Mol. Biol., 215, 1990, 403-410.

BAKER, C.J., EDWARDS, M.S.: Group B streptococcal infections. In: J.S. REMINGTON, J.O. KLEIN (Eds.) Infectious diseases of the fetus and newborn infant. WB Saunders, Philadelphia, 2000, 1091-1156.

BEVANGER, L., MAELAND, J.A. (1979): Complete and incomplete Ibc protein fraction in group B streptococci. In: Acta Pathol. Microbiol. Immunol. Scand., sect. B 87, pp. 51-54.

BLUMBERG, H.M., STEPHENS, D.S., LICITRA, C., PIGOTT, N., FACKLAM, R., SWAMINATHAN, B., WACHSMUTH, I.K.: Molecular epidemiology of group B streptococcal infections: use of restriction endonuclease analysis of chromosomal DNA and DNA restriction fragment length polymorphisms of ribosomal RNA genes (ribotyping). J. Infect. Dis., 166, 1992, 574-579.

BLUMBERG, H.M., STEPHENS, D.S., MODANSKY, M., ERWIN, M., ELLIOT, J., FACKLAM, R.R., SCHUCHAT, A., BAUGHMAN, W., FARLEY, M.M.: Invasive group B streptococcal disease: the emergence of serotype V. J. Infect. Dis., 173, 1996, 365-373.

BRADLEY, A.J.: Bovine mastitis: An evolving disease. Vet. J., 163, 2002, 1-13.

BRODEUR, B.R., BOYER, M., CHARLEBOIS, I., HAMEL, J., COUTURE, F., RIOUX, C.R., MARTIN, D.: Identification of group B streptococcal Sip protein, which elicits cross-protective immunity. Infect. Immun., 68, 2000, 5610-5618.

CALlEBAUT, I., GILGES, D., VIGON, I., MORNON, J.P.: HYR, an extracellular module involved in cellular adhesion and related to the immunoglobulin-like fold. Protein Sci., 9, 2000, 382-1390.

CHOTÁR, M., VIDOVÁ, B., GODÁNY, A.: Development of specific and rapid detection of bacterial pathogens in dairy products by PCR. Folia Microbiol., 51, 2006, 639-646.

DESWAUX, M., DUMAS, E., CHAFSEY, I., HÉBRAUD, M.: Protein cell surface display in Gram-positive bacteria: from single protein to macromolecular protein structure. FEMS Microbiol. Lett., 256, 2006, 1-15. 
EDWARDS, M.S., KASPER, D.L., JENNINGS, H.J., BAKER, C.J., NICHOLSONWELLER, A.: Capsular sialic acid prevents activation of the alternative complement pathway by type III, group B streptococci. J. Immunol., 128, 1982, 1278-1283.

FERRIERI, P.: Prevention of group B Streptococcus infections. Semin. Infect. Dis., 8, 1997, 117-124.

FLORES, A.E., FERRIERI, P.: Molecular species of R-protein antigens produced by clinical isolates of group B streptococci. J. Clin. Microbiol., 27, 1989, 1050-1054.

FLORES, A.E., FERRIERI, P.: Molecular diversity among the trypsin resistant surface proteins of group B streptococci. Zbl. Bakt., 285, 1996, 44-51.

GORDILLO, M.E., SINGH, K.V., BAKER, C.J., MURRAY, B.E.: Typing of group B streptococci: comparison of pulsed-field gel electrophoresis and conventional electrophoresis. J. Clin. Microbiol., 31, 1993, 1430-1434.

HAMBURGER, Z.A., BROWN, S., ISBERG, R.R., BJORKMAN, P.J.: Crystal structure of invasin: a bacterial integrin-binding protein. Science, 286, 1999, 291-295.

JONES, N., BOHNSACK, J.F., TAKAHASHI, S., OLIVER, K.A., CHAN, M.S., KUNST, F., GLASER, P., RUSNIOK, C., CROOK, D.W., HARDING, R.M., BISHARAT, N., SPRATT, B.G.: Multilocus sequence typing system for group B Streptococcus. J. Clin. Microbiol., 41, 2003, 2530-2536.

KONG, F., GOWAN, S., MARTIN, D., JAMES, G., GILBERT, G.L.: Molecular profiles of group B streptococal surface protein antigen genes: relationship to molecular serotypes. J. Clin. Microbiol., 40, 2002, 620-626.

KVAM, A.I., EFSTRATIOU, A., BEVANGER, L., COOKSON, B.D., MARTICORENA, I.F., GEORGE, R.C., MAELAND, J.A.: Distribution of serovariants of group B streptococci in isolates from England and Norway. J. Med. Microbiol., 42, 1995, 246-250.

LACHENAUER, C.S., CRETI, R., MICHEL, J.L., MADOFF, L.C.: Mosaicism in the alpha-like protein genes of group B streptococci. Proc. Natl. Acad. Sci., 97, 2000, 9630-9635.

LACHENAUER, C.S., KASPER, D.L., SHIMADA, J., ICHIMAN, Y., OHTSUKA, H., KAKU, M., PAOLETTI, L.C., FERRIERI, P., MADOFF, L.C.: Serotypes VI and VIII predominate among group B streptococci isolated from pregnant japanese women. J. Infect. Dis., 179, 1999, 1030-1033.

LACHENAUER, C.S., MADOFF, L.C.: A protective surface protein from type V group B streptococci shares $\mathrm{N}$-terminal sequence homology with the alpha $\mathrm{C}$ protein. Infect. Immun., 64, 1996, 4255-4260.

LANCEFIELD, R.C., PERLMANN, G.E.: Preparation and properties of a protein (R antigen) occurring in streptococci of group A, type 28 and in certain streptococci of other serological groups. J. Exp. Med., 96, 1952, 83-97.

LARSSON, C., HOLMGREN, J., LINDAHL, G., BERGQUIST, C.: Intranasal immunisation of mice with group B streptococcal protein Rib and cholera toxin B subunit confers protection against lethal infection. Infect. Immun., 72, 2004, 11841187.

LIMANSKY, A.S., SUTICH, E.G., GUARDATI, M.C., TORESANI, I.E., VIALE, A.M.: Genomic diversity among Streptococcus agalactiae isolates detected by a 
degenerate oligonucleotide-primed amplification assay. J. Infect. Dis., 177, 1998, 1308-1313.

LINDAHL, G., STÅLHAMMAR-CARLEMALM, M., ARESCHOUG, T.: Surface proteins of Streptococcus agalactiae and related proteins in other bacterial pathogens. Clin. Microbiol. Rev., 18, 2005, 102-127.

LUO, Y., FREY, E.A., PFUETZNER, R.A., CREAGH, A.L., KNOECHEL, D.G., HAYNES, C.A., FINLAY, B.B., STRYNADKA, N. C.: Crystal structure of enteropathogenic Escherichia coli intimin-receptor complex. Nature, 405, 2000, 1073-1077.

MADOFF, L.C., MICHEL, J.L., GONG, E.W., KLING, D.E., KASPER, D.L.: Group B streptococci escape host immunity by deletion of tandem repeat elements of the alpha C protein. Proc. Natl. Acad. Sci., 93, 1996, 4131-4136.

MAELAND, J.A., BEVANGER, L., LYNG, R.V.: Antigenic determinants of alphalike proteins of Streptococcus agalactiae. Clin. Diagn. Lab. Immunol., 11, 2004, 1035-1039.

MAIONE, D., MARGARIT, I., RINAUDO, C.D., MASIGNANI, V., MORA, M., SCARSELLI, M., TETTELIN, H., BRETTONI, C., IACOBINI, E.T., ROSINI, R., D’AGOSTINO, N., MIORIN, L., BUCCATO, S., MARIANI, M., GALLI, G., NOGAROTTO, R., DEI, V.N., VEGNI, F., FRASER, C., MANCUSO, G., TETI, G., MADOFF, L.C., PAOLETTI, L.C., RAPPUOLI, R., KASPER, D.L., TELFORD, J.L., GRANDI, G.: Identification of a universal Group B Streptococcus vaccine by multiple genome screen. Science, 309, 2005, 148-150.

MICHEL, J.L., MADOFF, L.C., OLSON, K., KLING, D.E., KASPER, D.L., AUSUBEL, F.M.: Large, identical, tandem repeating units in the $\mathrm{C}$ protein alpha antigen gene, bca, of group B streptococci. Proc. Natl. Acad. Sci., 89, 1992, 10060 10064.

MOYO, S.R., MAELAND, J.A., BERGH, K.: Typing of human isolates of Streptococcus agalactiae (group B streptococci, GBS) strains from Zimbabwe. J. Med. Microbiol., 51, 2002, 595-600.

MUSSER, J.M., MATTINGLY, S.J., QUENTIN, R., GOUDEAU, A., SELANDER, R.K.: Identification of a high-virulencce clone of type III Streptococcus agalactiae (group B Streptococcus) causing invasive neonatal disease. Proc. Natl. Acad. Sci., $86,1989,4731-4735$.

PAOLETTI, L.C., MADOFF, L.C.: Vaccines to prevent neonatal GBS infection. Semin. Neonatol., 7, 2002, 315-323.

PAOLETTI, L.C., MADOFF, L.C., KASPER, D.L.: Surface structures of Group B Streptococcus important in human immunity. In: V.A. FISCHETTI, R.P. NOVICK, J.J. FERRETTI, D.A. PORTNOY, J.I. ROOD (Eds.) Gram-positive Pathogens. ASM Press, Washington, D.C, 2000, 137-153.

PERSSON, E., BERG, S., BEVANGER, L., BERGH, K., VALSO-LYNG, R., \& TROLLFORS, B.: Characterisation of invasive group B streptococci based on investigation of surface proteins and genes encoding surface proteins. Clin. Microbiol. Infect., 14, 2008, 66-73.

ROLLAND, K., MAROIS, C., SIQUIER, V., CATTIER, B., QUENTIN, R.: Genetic features of Streptococcus agalactiae strains causing severe neonatal infections, as 
revealed by pulsed-field gel electrophoresis and HylB gene analysis. J. Clin. Microbiol., 37, 1999, 1892-1898.

SKINNER, F.A., QUESNEL, L.B.: Streptococci. Academic Press, New York, 1978, $415 \mathrm{pp}$.

SPELLEBERG, B.: Pathogenesis of neonatal S. agalactiae infections. Microbes Infect., 2, 2000, 1733-1742.

STÅLHAMMAR-CARLEMALM, M., STENBERG, L., LINDAHL, G.: Protein Rib: a novel group B streptococcal cell surface protein that confers protective immunity and is expressed by most strains causing invasive infection. J. Exp. Med., 177, 1993, 1593-1603.

WÄSTFELT, M., STÅLHAMMAR-CARLEMALM, M., DELISSE, A.M., CABEZON, T., LINDAHL, G.: Identification of a family of streptococcal surface proteins with extremely repetitive structure. J. Biol. Chem., 271, 1996, 1889218897.

ZALEZNIK, D.F., RENCH, M.A., HILLIER, S., KROHN, M.A., PLATT, R., LEE, M.L.T., FLORES, A.E., FERRIERI, P., BAKER, C.J.: Invasive disease due to group B Streptococcus in pregnant women and neonates from diverse population groups. Clin. Infect. Dis., 30, 2000, 276-281.

ZENG, X, KONG, F, MORGAN, J, GILBERT, G.: Evaluation of a multiplex PCRbased reverse line blot-hybridization assay for identification of serotype and surface protein antigens of Streptococcus agalactiae. J Clin Microbiol, 44, 2006, 3822-3825. 